\title{
EFFECT OF Nb ON THE PROPERTIES OF A LARGE-SIZED GRINDING BALL
}

\author{
VPLIV Nb NA LASTNOSTI VELIKIH KROGEL ZA DROBLJENJE
}

\author{
Mengchao Song ${ }^{1}$, Gaofeng Zheng ${ }^{1}$, Ran Wang ${ }^{1}$, Yisong Pu ${ }^{1 *}$, Baoqi Wang ${ }^{1}$, \\ Yahong $\operatorname{Tian}^{2 * *}$ \\ ${ }^{1}$ School of Materials Science and Engineering, Hebei University of Technology, no. 8 Dingzigu Road, Hongqiao District, \\ Tianjin 300130, China \\ ${ }^{2}$ School of Chemical Engineering and Technology, Hebei University of Technology, no. 8 Dingziguyihao Road, Hongqiao District, \\ Tianjin 300130, China \\ Prejem rokopisa - received: 2019-02-27; sprejem za objavo - accepted for publication: 2019-04-24
}

doi:10.17222/mit.2019.044

\begin{abstract}
Grinding balls are widely used in the mining industry due to their favorable properties; however, poor hardenability of largesized grinding balls is a limitation in wide applications. The hardenability and hardness of large-sized grinding balls can be affected by microalloying elements. In this work, $\mathrm{Nb}$ microalloying was used to improve the mechanical properties of largesized grinding balls. The microstructures and mechanical properties of Nb-containing grinding balls were studied in contrast to the Nb-free steel. Typical microstructures were observed with OM and SEM, respectively. The hardness was obtained with a Rockwell hardness tester. The results show that the typical microstructure of a large-sized grinding ball was mainly martensite and that the fracture surface consisted of dimples of different sizes. The prior-austenite grain size (PAGS) was decreased from $31.5 \mu \mathrm{m}$ to $22.6 \mu \mathrm{m}$ by adding $0.04 \% \mathrm{Nb}$ with a refined microstructure.

Keywords: grinding balls, prior-austenite grain size, microalloying element, hardenability
\end{abstract}

Zaradi dobrih lastnosti, se krogle za drobljenje veliko uporabljajo v rudarstvu, toda slaba prekaljivost zelo velikih krogel po njihovem preseku omejuje njihovo uporabnost. Prekaljivost in s tem povečanje trdote v globini velikih krogel lahko izboljšamo z mikrolegiranjem. V članku avtorji opisujejo izboljšanje mehanskih lastnosti velikih krogel za drobljenje rude $\mathrm{z}$ mikrolegiranjem na osnovi $\mathrm{Nb}$. Avtorji so mikrostrukturo in mehanske lastnosti jeklenih rudarskih krogel iz mikrolegiranega jekla z Nb, primerjali z jeklom, ki ni vsebovalo Nb. Tipične mikrostrukture jekel so opazovali pod optičnim (OM) in vrstičnim elektronskim mikroskopom (SEM). Trdoto krogel so določili z Rockwellovim merilnikom trdote. Rezultati raziskav so pokazali, da je bila tipična mikrostruktura velikih krogel sestavljena pretežno iz martenzita, saj so imele prelomne površine tipičen jamičast duktilni prelom z različno velikimi jamicami. Velikost predhodnih austenitnih zrn (PAGS; angl.: prior austenite grain size) se je v mikrostrukturi zmanjšala z $31,5 \mu \mathrm{m}$ na $22,6 \mu \mathrm{m}$ z dodatkom $0,04 \% \mathrm{Nb}$.

Ključne besede: velike rudarske drobilne krogle, velikost predhodnih austenitnih zrn, mikrolegirni element, prekaljivost

\section{INTRODUCTION}

A grinding ball, as an indispensable grinding medium, is the most consumed part in a semi-autogenous (SAG) mill. ${ }^{1-3}$ With the gradual enlargement of SAG mills, the diameter of a grinding ball must be increased to meet the requirements of working conditions. ${ }^{4-6}$ In a working process, a large-sized grinding ball is easy to peel off the block due to the lack of hardenability. ${ }^{7-8}$ And a grinding ball with poor wear resistance cannot meet the requirements for industrial applications. ${ }^{9}$ Under the conditions of wet grinding, the grinding ball is subject to wear and repeated impact, which accelerate the crushing rate. ${ }^{10-11}$ Thus, the grinding ball must have excellent mechanical properties such as hardenability and wear resistance to meet the working conditions. ${ }^{12-13}$ The hardness is directly dependent on the hardenability of the material, so a designed $\# 150-\mathrm{mm}$ grinding ball must exhibit high hardenability.

*Corresponding author's e-mail:

320420280@qq.com*, tianyahong0329@163.com**
$\mathrm{Nb}$ is widely used in steels as a microalloying element for grain refinement. ${ }^{14-16}$ In this work, the properties of $\mathrm{Nb}$-free and $\mathrm{Nb}$-containing grinding balls were investigated, and the feasibility of adding $\mathrm{Nb}$ to largesized grinding balls to improve their hardenability was studied.

\section{EXPERIMENTAL PART}

Experimental steels were smelted in a vacuum medium-frequency induction furnace, marked as $\mathrm{A}$ and $\mathrm{B}$. $\mathrm{A}$ was the $\mathrm{Nb}$-free steel and $\mathrm{B}$ was the $\mathrm{Nb}$-containing microalloyed steel. After having been forged at $1325 \mathrm{~K}$, ingots were processed into $85 \mathrm{~mm} \times 240 \mathrm{~mm}$ steel bars. The alloy composition was examined with inductively coupled plasma mass spectrometry (ICP-MS). The alloy

Table 1: Chemical composition of the experimental steel

\begin{tabular}{|c|c|c|c|c|c|c|c|c|}
\hline Steel & $\mathrm{C}$ & $\mathrm{Si}$ & $\mathrm{Mn}$ & $\mathrm{S}$ & $\mathrm{P}$ & $\mathrm{Cr}$ & $\mathrm{Nb}$ & $\mathrm{Fe}$ \\
\hline $\mathrm{A}$ & 0.87 & 0.82 & 1.1 & 0.0082 & 0.015 & 0.95 & - & Bal. \\
\hline B & 0.87 & 0.81 & 1.1 & 0.0089 & 0.013 & 0.95 & 0.04 & Bal. \\
\hline
\end{tabular}




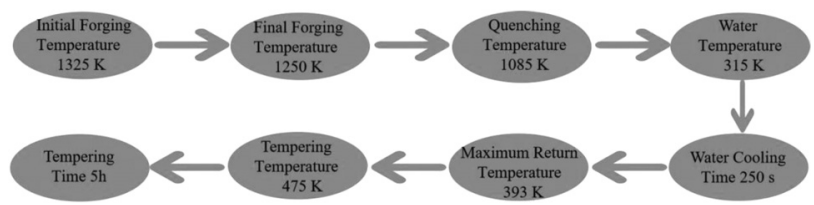

Figure 1: Heat treatment of grinding balls

elements are listed in Table 1. Figure 1 shows the heat treatment of grinding balls.

A grinding ball was cut into semi-circular pieces with a thickness of $11 \mathrm{~mm}$ using a wire-cut electric discharge machine, then the two cutting planes were ground. The hardness values were measured every $7.5 \mathrm{~mm}$ from the center to the surface using a Rockwell hardness tester with an accuracy of 0.1 HRC. To obtain the typical microstructure, samples were polished and etched with supersaturated $4 \%$ nitric acid in ethanol. Additional samples were heated in an electric furnace at a temperature of $1170 \mathrm{~K}$ for $3 \mathrm{~h}$. A saturated, aqueous picric acid solution was used to reveal the prior-austenite grain boundaries (PAGBs). The PAGSs were examined using the linear-intercept method of optical microscopy (OM). To obtain fractographs, the samples were cut along the loading direction and near the fracture lip. Then they were cleaned three times in an ultrasonic stirrer and the fracture surfaces were examined with an S-4800 scanning electron microscope (SEM).

\section{RESULTS AND DISCUSSION}

\subsection{Effect of the secondary phase on the grain size}

In accordance with the theory of the second-phase particles in iron and steel, the content of $\mathrm{Nb}$ in the solid

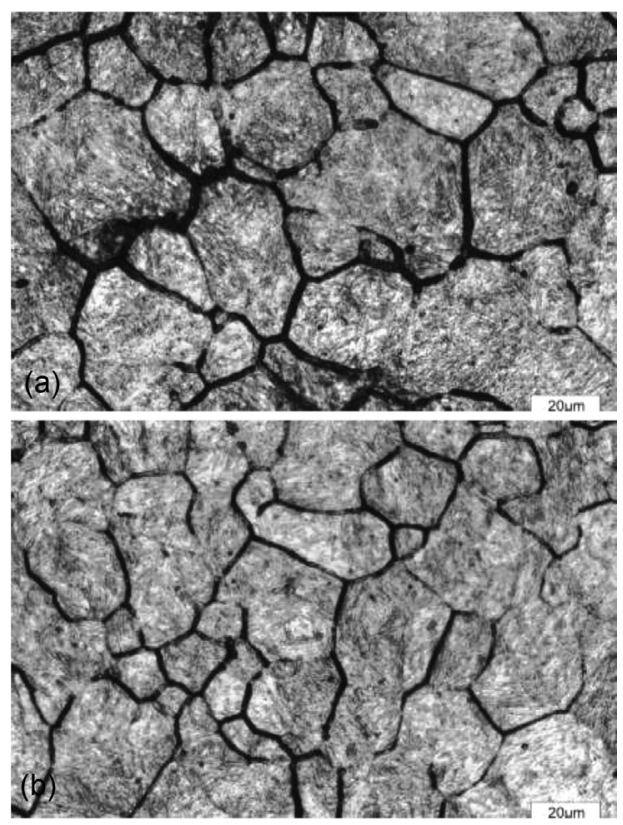

Figure 2: Images of the prior-austenite grain sizes: a) ball A at $1170 \mathrm{~K}$ held for $3 \mathrm{~h}, \mathrm{~b}$ ) ball $\mathrm{B}$ at $1170 \mathrm{~K}$ held for $3 \mathrm{~h}$ solution state was limited under a certain $\mathrm{C}$ content and the rest was precipitated in the form of the second phase. The compounds formed by $\mathrm{Nb}$ and non-metallic elements had a great solubility in the molten steel. The formula for the solid solubility of $\mathrm{Nb}$ in austenite is as follows: ${ }^{18-19}$

$$
\lg \left(c_{\mathrm{c}} \cdot c_{\mathrm{Nb}}^{0.875}\right)_{g}=2.97-\frac{7500}{T} \pm 0.06
$$

where $c_{\mathrm{C}}$ and $c_{\mathrm{Nb}}$ are the contents of $\mathrm{C}$ and $\mathrm{Nb}$ in austenite, respectively, and $\mathrm{T}$ is the temperature. Thus, most of the $\mathrm{Nb}$ elements were presented in the form of second-phase particles due to the fact that the $\mathrm{C}$ content of the experimental steel was $0.87 \%$ and the austenitizing temperature was $1025 \mathrm{~K}$. Figure 2 shows that PAGS of ball A was $31.5 \mu \mathrm{m}$ and that of ball B was 22.6 $\mu \mathrm{m}$, indicating that $\mathrm{Nb}$ played a great role in the grain refinement.

According to the Hall-Petch formula, the structure and properties of steel were directly affected by PAGS. ${ }^{20}$ The smaller the austenite grain, the better were the hardness and toughness of the steel.

$$
\sigma=\sigma_{0}+k \cdot d^{-1 / 2}
$$

Here, $\sigma_{0}$ is the lattice friction stress required for moving individual dislocations; $\mathrm{k}$ is the material-dependent constant known as the Hall-Petch slope; and $\mathrm{d}$ is the average grain size.

During the process of grain growth, the migration of grain boundaries was hindered by the secondary-phase
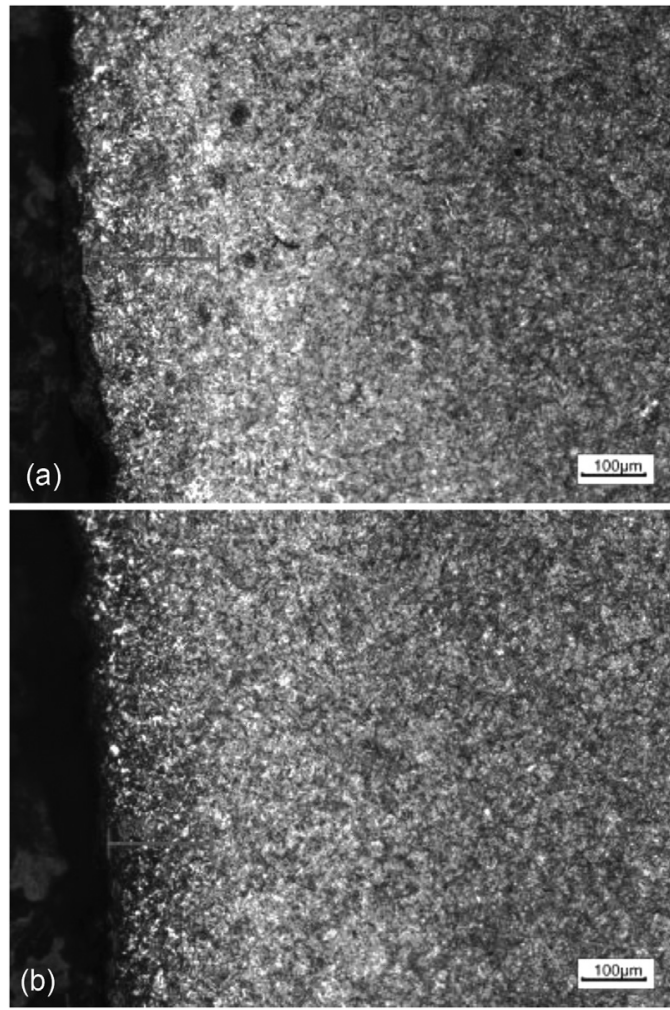

Figure 3: OM images of surface decarbonization: a) ball A heated at $1250 \mathrm{~K}$ for $5 \mathrm{~h}, \mathrm{~b})$ ball $\mathrm{B}$ heated at $1250 \mathrm{~K}$ for $5 \mathrm{~h}$ 


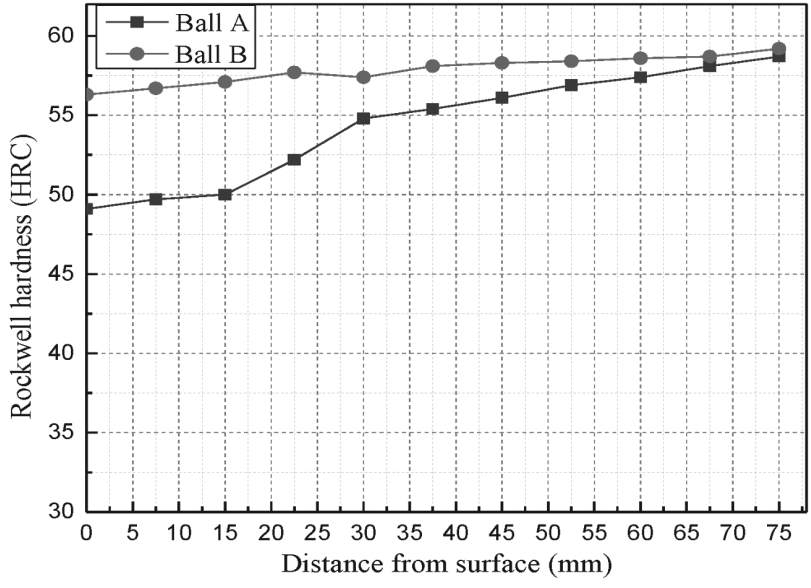

Figure 4: Hardness-distribution curves of the grinding balls

particles in ball B. When a grain encounters secondphase particles in the process of growth, the movement of the grain boundary is cut off. When the grain boundary reaches the maximum interface, its continuous movement increases the grain-boundary area. At this time, the particles drag the grain-boundary movement and pin the grain boundary. The deformation of grains at the grain boundaries is more coordinated, which makes them difficult to deform, hence a reinforcement of the grain boundaries occurs. ${ }^{18}$ Consequently, the secondary phase in the steel is critical for preventing the coarsening of austenite grains at high temperatures.

\subsection{Decarburization layer and the hardness measure- ment}

Figure 3 shows that the surface decarbonization of grinding ball A was more serious than that of grinding ball $\mathrm{B}$. The thickness of the decarburized layer on the surface of ball A was roughly $224 \mu \mathrm{m}$ and that of ball B was roughly $172 \mu \mathrm{m}$. The carbon diffusion rate decreased significantly with the addition of $\mathrm{Nb}$. The addition of $\mathrm{Nb}$ had a significant effect on reducing the decarbonization tendency at the surface, improving the degree of influence on the carbon diffusion and showing good decarbonization resistance.

Every hardness value was measured six times and averaged, and the hardness distribution was shown in Figure 4. From $1 / 4 \mathrm{R}$ to the surface, the hardness of grinding ball A was slightly lower than that of grinding ball B. From the center to $1 / 4 \mathrm{R}$, the hardness of ball A decreased sharply, resulting in an uneven stress distribution. In the working process, ball A was easy to crack and break. With the increase in the distance from the center, the hardness increased smoothly for ball B. The hardness range for ball $\mathrm{B}$ from the center to the surface was 56.3-59.2 HRC, and the hardness almost had a homogeneous distribution.

\subsection{Microscopic observation}

Figures 5 and $\mathbf{6}$ show that the microstructures of the surface, $1 / 2 \mathrm{R}$ and the center were obtained with OM. Figure 5 shows that the microstructure of grinding ball A was composed of martensite at the surface. The microstructure was mainly martensite and bainite at $1 / 2 \mathrm{R}$. At the center, the microstructure was mainly martensite and
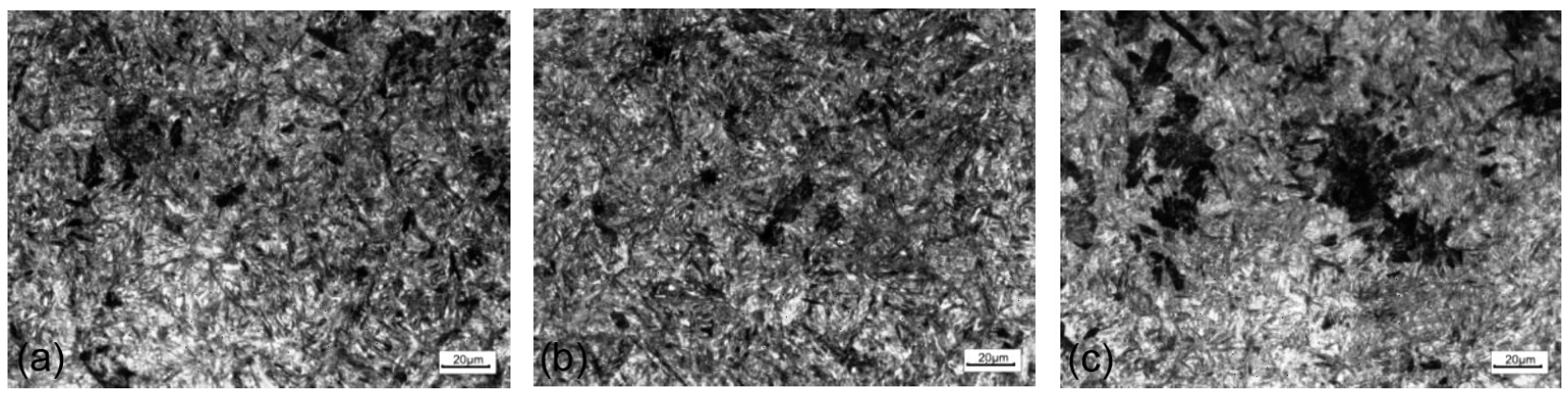

Figure 5: OM images of grinding ball A: a) surface, b) 1/2 R, c) center
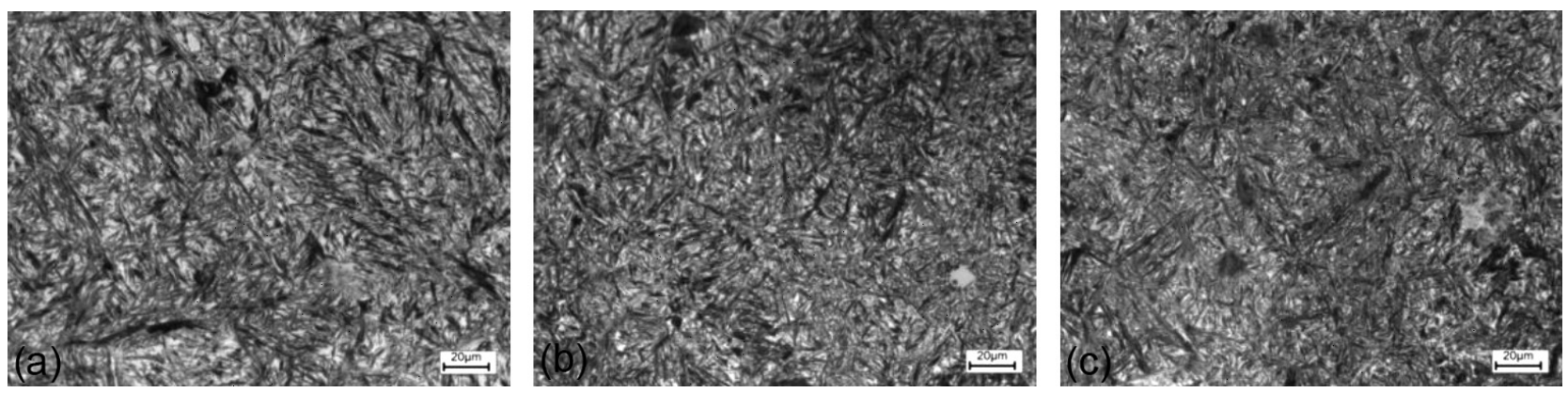

Figure 6: OM images of grinding ball B: a) surface, b) 1/2 R, c) center 

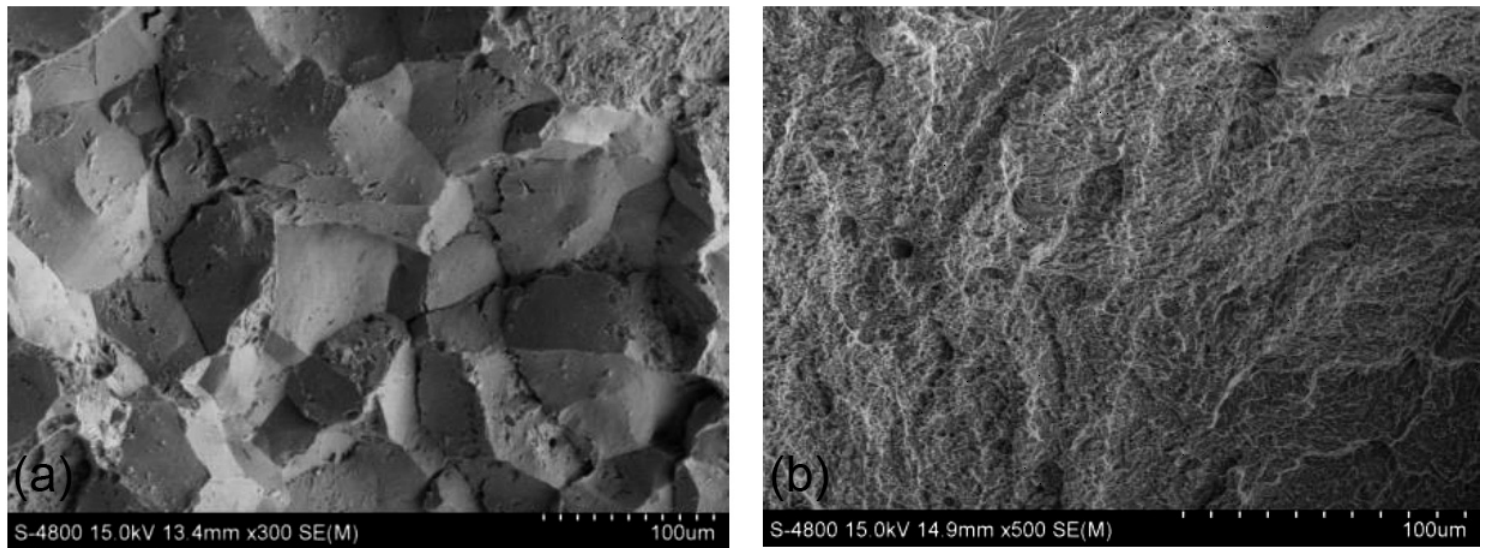

Figure 7: SEM fractographs of grinding balls: a) sample A, b) sample B

pearlite, of which the latter amounted to more than half. The center of grinding ball A was not hardened, so the performance was poor. Figure 6 shows that the surface of grinding ball B was a mixed martensite structure. At $1 / 2 \mathrm{R}$, the microstructure mainly included martensite and a very small amount of bainite. At the center, the microstructure was composed of martensite and a small amount of retained austenite (RA). A small amount of RA can improve the impact toughness and fracture resistance of a grinding ball. The distribution of martensite from the center to the surface was uniform and there was no preferred orientation. Thus, the addition of $\mathrm{Nb}$ made the grinding ball harden completely.

Figure 7 shows the fracture surfaces of samples A and B. A clear rock-sugar pattern can be observed on the surface of sample A. At the end of some grains, sharp surfaces with an angle of roughly 90 degrees can be seen. The fracture morphology of sample B includes dimples and tearing edges of different sizes, indicating ductile fracture. On the fracture surface of sample B, large dimples are surrounded by small dimples, which can absorb a large amount of deformation energy and hinder the initiation and propagation of cracks.

\section{CONCLUSIONS}

The effect of $\mathrm{Nb}$ on the properties of large-sized grinding balls was investigated in this research. It was concluded that a finely distributed $\mathrm{Nb}$-containing secondary phase can hinder the growth of the grains and refine the PAGS from $31.5 \mu \mathrm{m}$ to $22.6 \mu \mathrm{m}$. The distribution of martensite from the center to the surface was uniform, and the thickness of the decarbonized layer was obviously decreased. The fracture surface changed from a rock-sugar pattern to fine dimples; thereby, the toughness of large-sized grinding balls was greatly improved. The hardness range of the $\mathrm{Nb}$-containing grinding balls from the center to the surface was 56.3-59.2 HRC, and the hardness exhibited an almost homogeneous distribution.

\section{Acknowledgments}

Authors appreciate the contributions of the editors and the reviewers in ensuring the quality of the paper is improved.

\section{REFERENCES}

${ }^{1}$ K. P. Simba, M. H. Moys, Effects of mixtures of grinding media of different shapes on milling kinetics, Minerals Engineering, 61 (2014), 40-46, doi:10.1016/ j.mineng.2014.03.006

${ }^{2}$ D. Cuhadaroglu, S. Samanli, S. Kizgut, The effect of grinding media shape on the specific rate of breakage, Particle and Particle Systems Characterization, 25 (2009) 5-6, 465-473, doi:10.1002/ppsc. 200800001

${ }^{3} \mathrm{C}$. Aldrich, Consumption of steel grinding media in mills, Minerals Engineering, 49 (2013), 77-91, doi:10.1016/j.mineng.2013.04.023

${ }^{4}$ J. L. Salazara, L. Magneb, G. Acuñac, Dynamic modelling and simulation of semi-autogenous mills, Minerals Engineering, 22 (2009) 1, 70-77, doi:10.1016/ j.mineng.2008.04.009

${ }^{5} \mathrm{~S}$. Morrell, Modelling the influence on power draw of the slurry phase in autogenous (AG), semi-autogenous (SAG) and ball mills, Minerals Engineering, 89 (2016), 148-156, doi:10.1016/j.mineng. 2016.01.015

${ }^{6}$ W. Valery Jnr, S. Morrell, The development of a dynamic model for autogenous and semi-autogenous grinding, Minerals Engineering, 8 (1995) 11, 1285-1297, doi:10.1016/0892-6875(95)00096-9

${ }^{7}$ E. Albertin, S. L. Moraes, Maximizing wear resistance of balls for grinding of coal, Wear, 263 (2007) 1-6, 43-47, doi:10.1016/j.wear. 2007.02.013

${ }^{8}$ C. W. Li, Z. Y. Gao, Effect of grinding media on the surface property and flotation behavior of scheelite particles, Powder Technology, 322 (2017), 386-392, doi:10.1016/j.powtec.2017.08.066

${ }^{9}$ T. Chandrasekaran, K. A. Natarajan, Kishore, Influence of microstructure on the wear of grinding media, Wear, 147 (2007) 2, 267-274, doi:10.1016/0043-1648(91) 90184-V

${ }^{10}$ W. J. Bruckard, G. J. Sparrow, J. T. Woodcock, A review of the effects of the grinding environment on the flotation of copper sulphides, International Journal of Mineral Processing, 100 (2011) 1-2, 1-13, doi:10.1016/j.minpro.2011.04.001

${ }^{11}$ K. Ravishankara, P. S. Rameshb, B. Sadhasivama, Wear-induced mechanical degradation of plastics by low-energy wet-grinding, Polymer Degradation and Stability, 158 (2018), 212-219, doi:10.1016/j.polymdegradstab.2018.10.026

${ }^{12}$ C. Camurri, C. Carrasco, O. Z. Hernandez, Proposed heat treatment conditions to improve toughness of steel grinding balls, Metallurgia Italiana, (2007) 9, 23-29 


\section{SONG et al.: EFFECT OF Nb ON THE PROPERTIES OF A LARGE-SIZED GRINDING BALL}

${ }^{13}$ T. W. Chenje, D. J. Simbi, E. Navara, Relationship between microstructure, hardness, impact toughness and wear performance of selected grinding media for mineral ore milling operations, Materials \& Design, 25 (2004) 1, 11-18, doi:10.1016/s0261-3069(03)00168-7

${ }^{14}$ B. Chokkalingam, S. S. M. Nazirudeen, Investigations of microalloyed cast steels, Materials and Technology, 43 (2009) 3, 171-174

${ }^{15}$ G. Suleyman, E. M. Akif, K. Hasan, Effect of the addition of niobium and aluminium on the microstructures and mechanical properties of micro-alloyed PM steels, Mater. Technol., 50 (2016) 5, 641-648, doi:10.17222/mit.2015.248

${ }^{16}$ B. Chokkalingam, S. S. M. Nazirudeen, S. Ramakrishnan, Investigation into the mechanical properties of micro-alloyed as-cast steel, Mater. Technol., 45 (2011) 2, 159-163
${ }^{17}$ Q. L. Yong, Secondary Phases in Steel, Metallurgical Industry Press, (2006) 1, 39-57

${ }^{18} \mathrm{~S}$. Wu, X. C. Li, J. Zhang, Effect of $\mathrm{Nb}$ on transformation and microstructure refinement in medium carbon steel, Acta Metallurgica Sinica, 50 (2014) 4, 400-408, doi:10.3724/SP.J.1037.2013.00538

${ }^{19}$ L. Lin, B. S. Li, G. M. Zhu, Effects of $\mathrm{Nb}$ on the microstructure and mechanical properties of 38MnB5 steel, International Journal of Minerals, Metallurgy and Materials, 25 (2018) 10, 1181-1190, doi:10.1007/s12613-018-1670-z

${ }^{20}$ P. Lehtoa, H. Remesa, T. Saukkonen, Influence of grain size distribution on the Hall-Petch relationship of welded structural steel, Materials Science and Engineering: A, 592 (2014), 28-39, doi:10.1016/j.msea.2013.10.094 